\title{
EXCHANGE RATE EXPOSURE OF FIRMS AND THE DEMAND FOR FOREIGN EXCHANGE DERIVATIVES IN BRAZIL: DID HEDGE OR SPECULATION MATTER?
}

\author{
Fernando Nascimento de Oliveira *
}

\begin{abstract}
This paper examines empirically how the demand of foreign exchange derivatives by Brazilian corporations is related to their exchange rate exposure. With the help of an original database of 74,567 contracts written from 1999 to 2002 between corporations and financial institutions, we were able to identify the corporations that speculated and the ones that hedged with foreign exchange derivatives during this period. Our results show that the exchange rate exposure is positively related to the foreign operational exposures for firms that speculated and negatively related for firms that hedged in 2002. For the other years of the sample period, speculation or hedge did not affect the relationship between the exchange rate exposure and the foreign operational exposure of firms.
\end{abstract}

Keywords: Foreign exchange swaps; Hedge; Speculation; Corporations.

\section{Resumo}

Este artigo analisa empiricamente como a demanda de derivativos de câmbio por firmas brasileiras está relacionada as suas exposições cambiais. Com a ajuda de um banco de dados original de 74.567 contratos entre firmas e instituições financeiras de 1999 a 2002, somos capazes de identificar que empresas especularam e que empresas fizeram hedge durante o período. Nossos resultados mostram que a exposição operacional cambial das firmas está positivamente relacionada com a exposição cambial das firmas que especularam e negativamente relacionada com as firmas que fizeram hedge em 2002. Para os outros anos do período amostral, a especulação ou hedge não afetaram a relação entre a exposição operacional cambial e a exposição operacional das firmas brasileiras.

Palavras-chave: Swaps de taxa de câmbio; Hedge; Especulação; Corporações.

JEL classification: G13, G32, G38

\footnotetext{
* Banco Central do Brasil e IBMEC/RJ. E-mail: fernando.nascimento@bcb.gov.br
} 


\section{Introduction}

Brazil changed its foreign exchange regime in 1999 from a fixed exchange regime to a floating exchange regime. This change increased the foreign exchange exposure of corporations in Brazil. Not only did corporations, in general terms, started to export and import more, but they also issued more foreign exchange debt. In response to this, corporations increased their demand for foreign exchange derivatives as Oliveira (2004) shows. ${ }^{1}$

Novaes \& Oliveira (2007) point out that the demand for foreign exchange derivatives of corporations in Brazil during the period from 1999 to 2002 were of two kinds. One was to protect the cash flows of these corporations from relevant depreciations of the exchange rate, therefore for hedging purposes. The other was to obtain financial gains from the depreciation of the foreign exchange rate, which is for speculative reasons. ${ }^{2}$

The purpose of this paper is to study how the demand for foreign exchange derivatives of corporations both for hedge and speculation affected their exchange rate exposure from 1999 to 2002 . We are particularly interested in the year 2002, in which due to the presidential election process the foreign exchange rate depreciated almost $60 \%$ from January to December of 2002. Of course, the incentives for speculation and hedge in an economy like this get much pronounced. ${ }^{3}$

Our results show that the exchange rate exposure of corporations is positively related to the foreign operational exposure- defined as the difference between total exports and the sum of total imports and foreign exchange debt - for firms that speculated and negatively related for firms that hedged in 2002. However, firms that had negative operational exposure and that did not hedge had a negative correlation between this exposure and their exchange rate exposure.

We compare our results of the year 2002 with the results of hedge and speculation of the years from 1999 to 2001 . In these years the foreign exchange rate was much less volatile and average depreciation much less significant than in 2002. What we observe is that clearly 2002 is a very unique year as far as speculation and hedge is concerned. Not only the number of firms that

\footnotetext{
${ }^{1}$ Brazil's currency, the real, is nonconvertible, so it is not available for trade on the foreign exchange market and cannot be bought or sold outside Brazil. The Banco Central do Brasil maintains close control of the Brazilian currency market through Sisbacen, the Central Bank's information system. The system functions as a virtual environment where currency transactions and operations are officially authorized and conducted. Import and export operations must follow specific rules with regard to currency transactions. They include preparing contracts, documenting transactions and getting approval from Sisbacen. Almost all types of currency operations can be handled through a commercial bank or by local exchange brokers. Brazil is renowned for its range of regulatory and legal requirements, although some of these protectionist features have helped to insulate the country from the worst effects of the recent global financial crisis.

${ }^{2}$ The basic strategies to manage exchange rate risks in Brazil are similar to those used all over the world. Companies are subject to exchange rate fluctuations that can impact profitability and cash flows. But this currency volatility usually can be managed through derivatives, especially hedge contracts. The most common contracts are swaps, future, forward, and options. Operations with derivatives can be done through major banks. The main Brazilian provider of this type of financial services is BM\&F-BOVESPA, the Brazilian stock exchange.

${ }^{3}$ Figure A.1 shows the dynamics of the foreign exchange rate in Brazil from 1999 to 2002. As one can see, in 2002 the exchange rate increased sharply, from $\mathrm{R} \$ 2.31$ per dollar in January to $\mathrm{R} \$$ 3.50 per dollar in December - a depreciation of $60.0 \%$, which in part was due to uncertainties regarding the presidential elections. Therefore, the year 2002 seems to be a good candidate to capture uses of foreign exchange derivatives for speculation as well as for hedge.
} 
speculated and hedged from 1999 to 2001 is much less than the number of firms that speculated or hedged in 2002, but also the total demand of foreign exchange derivatives is much less. We show that during these years speculation or hedge did not matter for the relationship between the exchange rate exposure and the foreign involvement of corporations measured by their operational exposure.

To obtain our results, we built an original database of 74,567 contracts of foreign exchange swaps written between corporations and financial institutions from January 1999 to December 2002. Of these 25,457 are open at the end of 2002. This database allows us to identify the use of foreign exchange derivatives in order to hedge and in order to speculate from 1999 to 2002.

The data used in this study is obtained from confidential information of the Brazilian Central Bank. Additional available data from the two institutions that register the total volume of operations of foreign exchange derivates in Brazil - the Commodities and Futures Exchange (BM\&F) and the Center for Custody of Private Securities (CETIP) - show that, between 1999 and 2002, the contracts for exchange of interest denominated in BRL for dollardenominated interest (foreign exchange swaps) were by far the most important instrument of foreign exchange derivatives used by companies with operations in Brazil.

Based on this information, the Brazilian Central Bank solicited 50 authorized financial institutions that operate in the foreign exchange derivatives to inform the name of all the companies with which they signed contracts of foreign exchange swap from January 1999 to December 2002 as well as the notional amount, currency and maturity of these contracts.

In response to these information solicited by the Central Bank, 43 financial institutions described details of 74,567 contracts of foreign exchange swaps. Of these 25,457 were still outstanding at the end of 2002.

We show that 93 corporations had currency swaps positions open at the end of 2002. Of these 93 corporations, 16 held speculative positions for swaps that increased their foreign exchange risk. More precisely, these companies held open positions in swaps contrary to their operational currency exposure (difference between export revenues in dollars and the sum of imports expenses in dollars and debt in dollars). That is, companies that, due to operational currency exposure, lost (gained) with an appreciation (depreciation) of the exchange rate are long (short) in swaps, magnifying these monetary losses. On the other hand, of the 93 companies with contracts for open currency swaps 53 intended to diminish their currency exposure. Among these companies that hedged, $35,84 \%$ are concentrated in the utilities sector and all have dollar-denominated debt.

To study how the foreign exchange rate affected the value of firms we selected the group of 50 firms out of our group of 93 firms with more liquid stocks in Brazil in 2002. ${ }^{4}$ The number of these firms that speculated with these swaps was 14 and the number of firms that hedged was 36 .

The rest of the paper is organized as follows. Section 2 describes the data. Section 3 presents the theoretical background of the relation between the exchange rate and the market value of firms that speculated or hedged. Section 4 presents the main empirical analysis. Section 5 shows the robustness tests and section 6 concludes.

\footnotetext{
${ }^{4}$ Not many corporations in Brazil have liquid stocks.
} 


\section{The Data}

Our primary data source is a unique database, composed of 74,567 contracts of currency swaps signed between 1999 and 2002 between 43 financial institutions and non-financial corporations in Brazil. These contracts correspond to nearly $98 \%$ of the total volume of currency swaps transacted in $2002 .^{5}$

In order to understand the importance of our database, we need to explain briefly the prevailing structure of the Brazilian foreign exchange derivatives market from 1999 to 2002 . There were various types of foreign exchange derivatives used by firms and financial institutions: public bonds indexed to the dollar, operations with foreign exchange futures, options and forwards. In the currency swap contracts, the investor in the long position trades interest in BRL for dollar-denominated interest; this implies gains (losses) with depreciation (appreciation) of the exchange rate.

The initial demand for public bonds indexed to the dollar was made by the financial institutions and was registered in the System of Liquidation and Custody of Federal Public Securities (SELIC). The other derivatives were registered at Commodities and Futures Exchange (BM\&F) or at the Center for Custody of Public Securities (CETIP).

The main contracts of registered firms at $\mathrm{BM} \& \mathrm{~F}$ were future contracts and dollar options. According to available data at BM\&F in 2002, dollardenominated future contracts were only liquid for maturities within 20 days and their open total daily stock was almost always less than $3 \%$ of total open stock of currency swaps between firms and financial institutions registered at CETIP. Dollar options were even less liquid and present daily stock levels even lower than those of dollar-denominated future contracts.

The fact that currency swaps were the main instrument of foreign exchange derivatives used by corporations can be explained in part by simply observing the data. The data show that a great number of corporations that used foreign exchange derivatives had debt in a foreign currency. In general, this debt has middle to long-term maturities, with disbursement of interests done irregularly. Futures contracts, options or forward contracts of foreign exchange with long maturities are, in general, not liquid or inexistent, arising from this the need for corporations to demand counter operations, such as swaps, which better reflect the cash flow of their external obligations. ${ }^{6}$

The total volume of transacted currency swaps between firms and financial institutions is quite superior to the volume negotiated among non-financial firms. This fact is not peculiar to Brazil. Mian (1996) shows that, in the majority of countries, non-financial corporations seek financial institutions as the other party in their derivatives operations. Available data of the CETIP show that, between 1999 and 2002, the daily stock of currency swaps among corporations is on average 3\% of the daily stock of currency swaps done between financial institutions and corporations. Among the currency swaps, those for which the US dollar is one of the objects of operation represent more

\footnotetext{
${ }^{5}$ The Central Bank initially solicited information from 50 financial institutions. Some of these institutions were purchased by others of the group of 50, between 1999 and 2002. The purchasing financial institutions became responsible for the information regarding the contracts for currency swaps of those institutions that were purchased. This explains why the number of institutions that responded the initial request was 43 and not 50 .

${ }^{6}$ Other possible explanations are: the swaps do not need collateral (which is required by $\mathrm{BM} \& \mathrm{~F})$; they do not suffer daily adjusts and they also do not require an initial payment.
} 
than ninety-five percent of the total volume negotiated. ${ }^{7}$ Therefore, the Central Bank's database of US dollar-based currency swaps is fairly representative of the demand for foreign currency derivatives of Brazilian companies.

The empirical analysis will have as its focus the corporations that had open positions in currency swaps at the end of 2002. To get an idea of the kind of corporations we are dealing with, we compare them with the following control group: all of the non-financial corporations that do not pertain to the same economic group and have some form of exchange rate exposure. ${ }^{8}$ We consider a firm having exchange rate exposure if it has debt in foreign exchange, or exports or imports or is a part of a sector of the economy that has foreign exchange exposure. This group consists of 250 corporations that together with those that had open positions in currency swaps at the end of 2002, 93 corporations, comprise a total of 343 corporations. $^{9}$

Table B. 1 shows the financial characteristics of the corporations that had open positions and of those that do not. The corporations with open positions are larger, show more debt in US dollars, have greater ratios of external revenue to gross revenue and have more executives participating in the profits. In all of these cases, the hypothesis of average equality is rejected at the $5 \%$ significance level.

Of the 93 corporations in our sample, $7(7.13 \%)$ are multinationals. These corporations probably have a natural demand to hedge in order to protect the investment of their shareholders in the country of origin from fluctuations of the nominal exchange rate. By taking the multinationals out of the sample, the only difference is that the corporations with open positions in currency swaps in 2002 become smaller than those corporations without open positions. Next, we define which of these corporations hedged or which speculated. The corporations that hedged are those for whom the product between the open net position in currency swaps and what we call operational currency exposure (the difference between export revenues in dollars and the sum of the imports expenses and debt in dollars) is less than zero. This product can be negative in two cases: when a corporation has an operational currency exposure greater than zero and tries to protect itself from a currency appreciation taking short positions in dollars; and when it has an operational currency exposure less than zero and tries to protect itself from a currency depreciation taking long positions in dollars.

The corporations that speculated were those that the product of the operational currency exposure and the net open position of the currency swap was greater than zero. This case includes the corporations whose value would diminish due to currency depreciation, even when they opted for short positions in currency swap contracts, and those whose value would increase with a currency appreciation and would nonetheless remain in long positions in currency swaps.

In order to find the open net position of the firm in currency swaps, we transform all the values in BRL to dollars, using the exchange rate of the

\footnotetext{
${ }^{7}$ A great majority of these contracts have maturities of less than two years and on the other end of the contract are pre and post-fixed interest rates.

${ }^{8}$ The selection has as base financial statements of the exercise of 2002, which became public and available at the Comissão de Valores Mobiliários (CMV). We choose those that divulged all the necessary accounting information.

${ }^{9}$ Close to $90 \%$ of businesses in the sample are among the 1000 largest Brazilian companies in terms of net revenue in the year 2002, according to the annual Valor 1000 of August 2003.
} 
date the operation. Next, we verify all of the open operations at the end of 2002 (long and short) and we find the net position of each corporation as the difference between the total volume in dollars of the long positions and the total volume in dollars of short operations. Table C.1 presents a classification by sectors of the corporations that hedged or that speculated, and shows the form they chose (long or short positions), in addition to information about the operational currency exposure of each of the different sectors.

Table C. 1 shows that the number of corporations that speculated was less than the number of corporations that hedged. All of the corporations that speculated held long positions in dollars. This suggests expectations of currency depreciation. This occurs even among predominantly export sectors, such as food products and beverages. In terms of hedge, we can see that all corporations were also long in dollars. Corporations that hedged were primarily from the utilities sector. This is the sector that in the aggregate shows the most significant debt in foreign exchange relative to its assets.

There are some sectors in which the average of the ratio between the value of open net positions in currency swaps and net worth were relevant. This occurred, both in the case of hedge ( $8.0 \%$ in the case of Electro/Electronic) and in the case of $(4.0 \%$ for the food and beverage sector). Given that the firms of these sectors were long in dollars, this fact reveals, once again, the expectation on the part of the firms of substantial currency depreciation during 2002.

Table C. 2 shows that debt in dollars were ubiquitous among corporations that did hedge. All of them had debt in dollars and negative operational exposure. In addition, Table C. 3 shows that firms that export predominated in the case of speculation. Some of these firms also showed some imports expenses and debt in dollars, but in volumes inferior to those of their exports revenues. Finally, Table C. 4 shows that $84.94 \%$ of the corporations that speculated or that hedged are private domestic firms, whereas only $7.93 \%$ are state-owned and $7.13 \%$ are multinationals. This proves that the decisions to hedge or speculate were made primarily by domestic agents.

Appendix Appendix E show the number and sectors of firms that speculated and hedged from 1999 to 2001 respectively with foreign exchange swaps. Table D.1 shows that the number of firms that speculated in 1999 was 6. Likewise in 2002, most corporations that hedged came from the utilities sector of the economy. Most of the corporations that hedged came from the electro/electronic sector of the economy.

Table D. 2 shows the number of firms that speculated and hedged with foreign exchange exposure in 2000. The number of firms that hedged during the period was 32. The number of firms that speculated was 5. Most corporations that hedged came from the utilities sector and most corporations that speculated came from the eletro/electronic sector. Interesting to note is that some firms that speculated in this year held short positions in the foreign exchange.

Table D.3 shows the number of firms that speculated and hedged with foreign exchange exposure in 2001. The number of firms that hedged was 40 and all were long in the foreign exchange rate. The number of firms that speculated was 13. Once more, most of the firms that hedged came from the utilities of public services. Most of the firms that speculated came from food and beverages sector of the economy.

As far as hedge is concerned, Appendix Appendix E shows that the behavior of firms in the years from 1999 to 2001 was similar to those firms that hedged in 2002. All had negative operational exposure, basically related to 
a high level of foreign exchange debt, and took long position in foreign exchange swaps. However, speculation in these years differed a little bit from speculation in 2002. In most cases, corporations that speculated were exporters that held long positions in foreign exchange rate. But in rare cases, notably in 2000 when the volatility of the exchange rate was very low, some prefered speculating with the appreciation of the exchange rate.

Finally, Table E. 1 shows the financial characteristics of the 50 firms of our group of 93 firms with more liquid stocks in Brazil at the end of 2002. It also shows mean tests of the comparisons between the characteristics of this group and the control group of 250 firms and the group of 93 firms with open foreign exchange swap positions in 2002. We use the liquidity index defined by Economatica. ${ }^{10,11}$ Not many corporations in Brazil have liquid stocks. Amongst the more liquid stocks there are several preferred and ordinary stocks of the same firm. Of the 50 firms, 14 speculated and 36 hedged. All firms held long positions in foreign exchange swaps. Table C.3 shows that the group of firms with more liquid stocks were larger firms, with more external debt and more export revenues than the other two groups.

\section{The Exchange Rate Exposure and the Foreign Exchange Involvement}

In this section, we study how the exchange rate is related to the market value of firms what we define as exchange rate exposure. Then we study how the exchange rate exposure is related to foreign operational exposure of firms and with their demand of derivatives for hedge or speculation.

Foreign exchange exposure can be decomposed into the effect of net monetary assets with fixed nominal payoffs and the value of real assets held by the firm. If we abstract from inflation uncertainty, short-term foreign monetary assets are in general fully exposed to exchange risk whereas domestic monetary assets are not. This is usually called translation exposure. Real assets however will be affected in value by foreign exchange movements, whatever their location. Thus purely domestic firms, like utilities, may be affected by the exchange rate movements, through effects on aggregate demand or on the cost of traded inputs; domestic firms that sell goods competing with imports will also be exposed to exchange rate movements.

\footnotetext{
${ }^{10}$ The Economatica system is a powerful and user-friendly tool designed for the analysis of equities and investment funds. It consists of a suite of advanced analytical modules which operate on top of a comprehensive and extremely reliable database. The system offers information on companies listed on the exchanges of United States, Brazil, Argentina, Chile, Mexico, Peru, Colombia and Venezuela. The user can subscribe to the complete database or to only the countries of interest. The database provides many years of historical data: - Quarterly Financial Statements Daily Stock Prices Corporate Actions (dividends, splits, etc.)The Economatica system calculates various types of indicators: - Financial indicators (ROE, ROIC, debt to equity ratio, etc); Fundamental indicators (P/E, EV/EBITDA, Dividend Yield, etc.);Statistical indicators (beta, volatility, liquidity, Sharpe, etc.) — Graphical indicators (RSI, stochastics, Bollinger bands, etc.). The data can be expressed in different currencies or adjusted by inflation indices. Also available are the historical series of macroeconomic and financial indicators. The historical pricing series are adjusted for corporate actions (dividends, splits, etc.).

${ }^{11}$ Stock Liquidity index of Economatica is defined as: $100 * \frac{p}{P} * \sqrt{\frac{n}{N} * \frac{v}{V}}$, where: $p(\operatorname{small})=$ number of days in which there were at least 1 trade of the stock during the period; $P(\max )=$ total number of days in the period; $n($ small $)=$ number of trades of the stock during the period; $N(\max )$ $=$ total number of trades of all the stocks in the period; $v($ small $)=$ volume in monetary terms of the stock in the period $V(\max )=$ total volume in monetary terms of all the stocks in the period
} 
The literature has identified several market imperfections or frictions that may justify the use of foreign exchange derivatives for hedging or speculative reasons so as to add market value to firms.

Smith \& Stulz (1985) argue that a hedge is a method by means of which corporations can reduce the volatility of their cash flow. The choice to hedge occurs more frequently among firms with greater costs of bankruptcy or greater probabilities of bankruptcy.

Myers (1977) demonstrates that indebted businesses have distorted incentives in terms of their policies for investment. To summarize, the distortion occurs due to the priority that the creditors have over the shareholders for receiving cash flow generated by corporations. Given this priority, the shareholders do not have incentives to contribute resources for investments whose returns-because of the highly indebted situation-will likely be used in the payment of debt. Excessive debt, however, can impede lucrative projects from being implemented. Thus, creditors anticipate the conflict of interest and incorporate their costs in the interest rate.

Mayers \& Smith (1982) show that a hedge reduces the probability of a company not fulfilling its obligations, thus reducing the probability that the investments are distorted, consequently, benefiting the shareholders through the reduction of the interest rate. Hedging, therefore, takes a firm's investment policy closer to that which maximizes the firm's value.

On the other hand Jensen \& Meckling (1976) argue that business with great amounts of debt can choose excessively risky investments. Following this thread, Géczy et al. (1997) show that costs of agency with creditors can induce the businesses to speculate. This can occur if shareholders turn their shares into options above the value of a leveraged firm, speculating to increase the volatility of the firm's cash flow when close to bankruptcy.

We have, therefore, two conflicting forecasts. On the one hand, Mayers \& Smith (1982) argue that corporations highly in debt are more likely to hedge. On the other hand, Géczy et al. (1997) argue that corporations with significant debt have greater incentive to speculate. In order to determine which of these effects prevail, we use two variables to capture costs of a suboptimal investment policy: the ratio between the total value of fixed assets and the size of the corporation and the ratio of the market value of corporation and its book value.

In contrast, a high ratio between a corporation's market value and the book value suggests that future gains (embedded in the market value of the firm's shares) still do not correspond to the value of the existing assets. Such a corporation should have greater difficulty offering real collateral to creditors compatible with the profitability of the existing investment opportunities. Thus, we expect a positive relationship between the ratio of the market value and book value and the probability of hedging or speculation.

Another characteristic of a firm related to its cost of agency with creditors is its size. Larger firms, in general, have greater reputation, a fact that can reduce the costs of agency. Therefore, we can expect that the size, defined as above, reduce the probability of the firm using hedge or speculation.

De Marzo \& Duffie (1991) suggest that corporations with greater asymmetry of information between executives and shareholders can obtain larger profits by hedging. De Marzo and Duffie are concerned with the shareholders' capacity to choose from their portfolios of assets. Hedging reduces the volatility of the companies' cash flow that, in turn, reduces the uncertainties 
of the shareholders' set of information. Consequently, the shareholders accept a hedge because this improves their portfolio choices. As an empirical approximation for asymmetric information between executives and shareholders we use the number of institutional investors of the firm. The idea is that institutional investors invest in the acquisition of information diminishing the uncertainty about the value of the firms in their portfolios. Therefore, a great number of institutional investors indicate a lesser probability of the firm performing a hedge.

The volatility of their compensation imposes costs to executives or controllers contrary to risk. Stulz (1984) and Smith \& Stulz (1985) argue that if the optimum contracts for compensation of executives or controllers contrary to risk are related to the volatility of the corporation' revenue or cash flow, these volatilities can be costly for these agents. If the executives or controllers do not manage to hedge on their own, or if it is up to the corporations to choose to hedge, then a hedge done by the firm can increase the well being of the administrators.

We use one variable as approximations for the executive's risk exposure: one binary variable equal to one if the executive has participation in profit and zero otherwise. The participation in profits is obtained by the firms' financial statements provided by CVM. ${ }^{12}$

Mian (1996) argues that risk management programs by means of derivatives can present initiation, implementation and maintenance costs. If these costs are significant, a company may not use these programs. Such costs present economies of scale related to the size of the firm. Therefore, the size of the firm-measured by the log of assets-can be positively related to the probability of hedging or the probability of speculation.

In our regressions, we use as a control variable a binary variable equal to one if the firm is multinational and zero otherwise. Multinational corporations can be interested in protecting the interests of shareholders in the origin country against fluctuations of the nominal exchange rate, even without possessing export revenues, import expenses or debt in dollars. In this case, multinational firms should be more likely to use a hedge and less likely to speculate.

Corporations with revenues from exports or expenses from imports are natural candidates to speculate with foreign exchange derivatives. The nature of their activities, makes these corporations follow regularly the foreign exchange market, maintaining close contact with agents that are probably the first to detect changes in the trends of the nominal exchange rate (dealers of foreign currency, for example). Therefore, they can participate in the foreign exchange market using privileged information. Our a priori is that corporations, which have relative relevant export revenues are more likely to speculate.

There is growing empirical evidence on the use of foreign exchange derivatives. Mian (1996) finds substantial use of hedging activity. Géczy et al. (1997) find in a sample of Fortune 500 firms that $52.1 \%$ use currency derivatives, 44.2 use interest rate derivatives, while only $11.3 \%$ use commodity deriva-

\footnotetext{
${ }^{12}$ The empirical literature makes use of the total shares or of the total volume of options of shares of the corporations in the hands of the executives to study the relationship between the volatility of their compensation and the cash flow of corporations. Such variables are not available in Brazil.
} 
tives. Novaes \& Oliveira (2007) show that many corporations in Brazil use currency derivatives to speculate.

Although there are numerous studies that theorize as to the value of hedging or speculation and a large number of studies that document the size and scope of theses activities, very few studies examine the relationship between the use of currency derivatives and the market value of firms. One of the rare studies is Allayanis \& Ofek (2001). They confirm the widespread use of currency derivatives: $42.6 \%$ of their sample of 378 firms use currency derivatives and on average cover $14.5 \%$ of foreign sales.

We use a two step regression methodology to measure the relation between foreign exchange exposure and the market value of firms, similar to Allayanis \& Ofek (2001). However our methodology is different from Allayanis and Ofek regarding the second step regressions as we will explain below.

The first regression is very standard in the literature. We regress for each of our 50 firms of our initial group of 93 firms with more liquid stocks at the end of 2002 their daily return on the depreciation of the exchange rate and the return of a market index, the IBovespa, as in equation (1). We are interested in the coefficient of the depreciation of the exchange rate, that we from now call the exchange rate exposure of the firm. We repeat the estimation (1) for all firms in the four years, 1999, 2000, 2001 and 2002 and find four distinct betas for each firm, one for every year of the sample.

$$
R_{i t}=\beta_{0}+\beta f_{\Delta f} x_{t}+\beta M R M_{t}+u_{t}, t=1991,2000,2001 \text { and } 2002, i=1,50
$$

where: Rit is the daily return of the stock of the firms, $\Delta f x_{t}$ is the daily depreciation of the exchange rate and $R M_{t}$ is the daily return of the IBovespa index and ut is a white noise disturbance. We estimate these regressions for every year using OLS; $\beta f$ measures the exchange rate exposure.

In the second step regressions, we use the following cross section regression (2) for each year:

$$
\begin{aligned}
\beta_{f i t}= & \delta_{0}+\delta_{1} o p s_{i t}+\delta_{2}(\text { spec } * o p s)_{i t}+\delta_{3}(\text { hedge*ops })_{i t}+\delta_{4}(\text { size })_{i t}+ \\
& \delta_{5} \text { mult } t_{i t}+\delta_{6} \text { part }_{i t}+\delta_{7} i i_{i t}+\delta_{8} \text { fixedasset }_{i t}+\delta_{9} m v b v_{i t}+u_{i t}, \\
& t=2002,2001,2000,1999 \text { e } i=1,50
\end{aligned}
$$

The betas are the exchange rate exposures obtained in equation (1) above. We regress them for every year against the following variables related to the theoretical reasons for firms to speculate and hedge with foreign exchange derivatives: ops is operational exposure, defined as the difference between exports and the sum of imports and foreign exchange debt; spec is equal to 1 if the firms speculated, hedge is equal to 1 if the firm hedged; mult is equal to one if the firm is multinational; fixedassets is the total fixed assets of the firm divided by total assets; size is the the log of the total assets of the firms; mvbv is the quotient between the market value of firms and their book value; part is one if the executives have participation in the profits of the firms; ii are the number of institutional investors of the firms.

In the next section we will show our estimations of our two step regressions methodology presented above. 


\section{Empirical Analysis}

\subsection{Exchange Rate Exposure}

We start presenting the results of the first step regressions, equation (1). We estimate equation (1) using Ordinary Least Squares (OLS). We repeat the regression for all years from 1999 to 2002. Table F.1 describes the several exchange rate exposures, or $\beta f$, obtained. In all regressions we correct for heterocedasticity and serial correlation using Newey \& West (1987) when necessary.

Our results are similar to others in the literature, such as Jorion (1990) for example. There are a great number of non-significant betas. In all years positive betas are related to firms that have positive operational exposure and negative beats are related to firms that had negative operational exposure. Due to the great number of non-significant betas, we consider important to verify if all the coefficients are jointly equal to zero. Equal coefficients could also reveal the endogenous nature of the relation between stock prices and exchange rates, which in this case could be unrelated to the foreign exchange exposure. To do this, we perform a weighted least square estimation of a system of equations for each one of the years and for the whole sample. Table F. 2 shows the results for 4 categories we select: the whole sample, the 30 more liquid stocks, only the firms that speculated and only the firms that hedged. The hypothesis of equal coefficients to zero is rejected for all groups defined and in all years.

\subsection{The Determinants of the Exchange Rate Exposure}

We now move on to the presentation and analysis of the results of our second step regressions. The results of the OLS estimations are presented in Table G.1. As the Table shows, the p-values of the F statistics of the test of the joint significance do not reject the overall significance of the variables. Although they are not reported in the table, we also do several diagnosis tests for omitted variables. In particular, we include squared terms of the independent variables that are not dummy variables and verify that the coefficients of these additional variables are not collectively different from zero. ${ }^{13}$ These tests indicate a correct specification of the model.

Column A of Table G.1 shows the results with all the control variable we mentioned above that we consider important to explain how speculation and hedge relate to the market value of firms. Column B shows the results of the estimation for a more simplified specification, containing only operational exposure and the interaction variables between hedge and speculation and operational exposure.

Let us start with speculation. All firms that speculated had positive operational exposure and positive exchange rate exposure. The sum of the coefficients of the speculation interaction term with operational exposure for the more complete specification is 0.23 with $p$-value of 0.04 . This means that speculation increased the exchange exposure of firms in 2002 as we would imagine. This continues to hold in the more simplified specification. For the more simplified specification we see that the sum of the two coefficients continues to be positive, 0.67 , and significant $\mathrm{p}$-value of 0.04 .

\footnotetext{
${ }^{13}$ For example, for the mentioned estimation for the probability to hedge, the $\mathrm{p}$-value of the test for omitted variables is 0.35 , whereas for the estimation for the probability to speculate the $\mathrm{p}$-value is 0.22 .
} 
Now we look at the firms that hedged. As we pointed out above all firms that hedged had negative operational exposure and negative exchange rate exposure. The sum of the operational exposure with the term that interacts with the hedge variable is negative, -0.24 , and significant, $p$-value 0.04 . This means that firms that hedged observed a negative relation between their foreign exchange involvement and their exchange rate exposure. This means that hedge helped these firms cope with the high level of depreciation of the exchange rate in 2002. On the contrary, firms that did not hedge and had an increase in their negative operational exposure-related to an increase in their foreign exchange debt for example- observed an increase in absolute terms in their foreign exchange exposure. This continues to be evident also in the more simplified specification, where the sum is -0.34 and p-value of 0.0 .

Economies of scale also affect positively the exchange rate exposure, as the value and p-value of the coefficient in columns (A) makes clear: the coefficient is 9.22 and p-value 0.09 .

The fact that a firm is multinational affects negatively the exchange rate exposure: the coefficient is -1.11 and $p$-value of 0.07 . It was what we expect a priori, given that, as we have already argued, multinationals possess natural demand to hedge.

The data do not identify aversion of risk of executives or controllers as a determinant in the choice to hedge. The participation in profits and the number of institutional investors were also not significant in affecting the probability to hedge. Finally, the quotient between the market value of the firm and its book value is also non significant.

Concluding, we can confirm that, in 2002, the results of our estimations furnish evidence that speculation increased the exchange rate exposure and hedge decreased it. Following, we look if these results continue to be the same in other years of our sample.

\subsection{Analyzing the Influence of Hedge and Speculation in Other Years}

In this section, we want to compare the year 2002 with the other years of our sample period to see if the relation between the foreign exchange and the market value of firms continues to be same as in 2002. Between 1999 and 2001 , the volatility of the exchange rate was much lower than it was during 2002. Even in 1999, the currency crisis occurred in the beginning of the year and lasted for much less time than the currency crisis in 2002. Therefore, the incentives, especially for speculation, are quite different than those of 2002.

We look at open foreign exchange swaps at the end of each year. We consider the net position, long minus shot in foreign exchange. We use again the same definition as before for hedge and speculation, reverse or neutral.

Our results for the year 2001 are in presented in Table H.1. As we can see, the results are different from the ones we obtained for 2002, as column (A) with the more complete specification shows. Both hedge and speculation do not affect anymore the relation between the exchange rate and the foreign exchange involvement. The coefficient of operational exposure is positive, which means that exporters in these years with less foreign debt and imports observed a positive relation between the foreign exchange and their market value. This is confirmed in the more simple specification as in column (B) of Table (A) makes clear. 
Our results for the year 2000 are presented in Table H.2. They resemble the ones of 2001. Both hedge and speculation once again did not anymore affect the relation between the exchange rate exposure and their foreign operational exposure. Finally, Table H.3 presents the results for 1999 which once again are very similar to the ones of 2000 and 2001.

The year 2002 seems to be unique as far as speculation and hedge are concerned. Firms that were able to speculate or hedge improved their market value. On the contrary the low volatility of the exchange rate in the other years did not provide the right incentives for firms to speculate or hedge with foreign exchange derivatives.

The results indicate that the year 2002 was particularly atypical in terms of incentives placed for speculation. Possessing privileged information in the market made exporters take advantage of these incentives in 2002. In the next section, we start testing the robustness of our results.

\section{Robustness Analyses}

\subsection{Panel Analysis}

In our first attempt to test the robustness of the results, we use a balanced panel for the years from 1999 to 2002, such as equation (3) below. We interact a dummy variable indicating the year 2002 with speculation or hedge. We use a random effects panel. ${ }^{14}$

$$
\begin{aligned}
\beta_{f i t}= & \delta_{0}+\delta_{1} \text { ops }_{i t}+\delta_{2}(\text { spec*ops })_{i t}+\delta_{3}(\text { spec*ops*y2002) })_{i t}+ \\
& \delta_{4}(\text { hedge*ops })_{i t}+\delta_{3}(\text { hedge*ops*y2002) })_{i t}+\delta_{5}(\text { size })_{i t}+ \\
& \delta_{6} \text { mult } t_{i t}+\delta_{7} p^{p a r t} t_{i t}+\delta_{8} i o_{i t}+\delta_{9} i m o b_{i t}+\delta_{10} m v b v_{i t}+a_{i}+u_{i t}, \\
& t=2002,2001,2000,1999 \text { e } i=1,50
\end{aligned}
$$

where $y 2002$ is a dummy variable equal to 1 if the year is 2002 and 0 for other years, ai is the fixed effects and the other variables are the same as in equation (2).

Table I.1 shows again that the year 2002 was special for speculation or hedge. Let us start with the results of speculation. All firms that speculated as we said had positive operational exposure. The coefficient of the interaction between speculation, operational exposure and the year 2002 is positive 0.03 and significant ( $p$-value 0.04 ). This means that firms that speculated at 2002 saw a positive relation between their exchange rate and their foreign involvement. Something similar happened for the more simplified specification, the value of the coefficient 0.05 and $\mathrm{p}$-value 0.01 .

For the firms that hedged the results are similar to the previous ones. As we pointed out above all firms that hedged had negative operational exposure. The coefficient of the interaction between hedge, operational exposure and the year 2002 is negative -0.07 and significant (p-value 0.02 ). The sum of the operational exposure with the term that interacts with the hedge variable is negative and significant. This means that firms that hedged observed a negative relation between their foreign exchange involvement and their exchange rate exposure.

\footnotetext{
${ }^{14}$ The p-value of the Haussman test is 0,40 .
} 


\subsection{Changing the Definition of Operational Exposure}

In our second attempt to test the robustness of the results, we changed our definition of foreign operational exposure in two different ways. Firstly, we extend the definition taking in consideration the net financial positions of firms in foreign exchange. To get we this we calculated the net position as the sum of the long positions in foreign exchange swaps with long position in other foreign exchange assets, like bonds or participation in firms abroad. Secondly, we move to a more simple operational definition considering only exports minus imports.

Table J.1 and J.2 present the results of our estimations with these two different definitions. Once again, speculation and hedge were relevant in 2002 and show a positive relation between the exchange rate and the foreign exchange exposure in the case of firms that speculated and a negative relation in the case of the firms that hedged.

\subsection{Modifying Total Exports and Total Imports}

In a third attempt to test the robustness of our results, we consider other values for total exports and imports. We consider only current export revenues and import expenses, that is, those related to the 2002 fiscal year. Nevertheless, it is possible that exporter or importer firms decide to speculate or hedge in a certain year taking into account the expected value of future fluxes of export revenues and import expenses. To analyze this possibility, we supposed that the expected future values of these revenues or expenses are equal to their 2002 values. We then defined foreign operational exposure as the present value of export revenues minus the sum of debt in dollar and the present value of import expenses. Note, however, that the positions of hedging, neutral speculation and reverse speculation continue to be defined by the sign of the product between the net position of open swaps and the operational currency exposure.

We verify that the change in the definition of operational currency exposure does not alter the classification of hedging and speculation for any of the 93 corporations with open positions in currency swaps nor our previous results.

\section{Conclusion}

In this paper, our purpose was to study the relation between the foreign exchange rate and the foreign exchange involvement of firms in Brazil. In particular, we wanted to answer the following question: Did speculation or hedge have any effect in this relation?

To obtain our results we built an original database of 74,567 contracts of foreign exchange swaps written between corporations and financial institutions from January 1999 to December 2002. Of these 25,457 are open at the end of 2002. Looking at these contracts we identified 93 corporations with open position in foreign exchange swaps. Of these 93 corporations, 53 demanded swaps in order to hedge. Or rather, the contracts to swap reduce the firms' exposure to currency risk and 40 firms demanded derivatives to speculate. 
Our results show that corporations that speculated in 2002 observed a positive relation between their foreign operational exchange exposure - defined as the difference between total exports and the sum of total imports and foreign exchange debt - and their exchange rate exposure, defined as the elasticity of the market value of the firm in respect to the exchange rate. However firms that had negative operational exposure and that did not hedge observed a positive relation between their foreign involvement and their exchange rate exposure.

We compare our results of the year 2002 with the results of hedge and speculation of the years from 1999 to 2001. In these years the foreign exchange rate was much less volatile and average depreciation much less significant than in 2002. What we observe is that clearly 2002 is a very unique year as far as speculation and hedge is concerned. We show that during these years speculation or hedge did not matter for the relationship between the exchange rate and the foreign operational exposure of firms.

In summary, this study indicates that, in periods of great volatility of the exchange rate-as in the year 2002 - the incentives for hedge and speculate were so relevant that they impacted significantly the exchange rate exposure and therefore the market value of firms.

\section{Bibliography}

Allayanis, G. \& Ofek, E. (2001), 'Exchange rate exposure, hedging and the use of foreign exchange derivatives', Journal of International Money and Finance 20, 273-296.

De Marzo, P. \& Duffie, D. (1991), 'Corporate financial hedging with proprietary information', Review of Financial Studies 8, 743-771.

Géczy, C., Minton, A. B. \& Schrand, C. (1997), 'Why firms use currency derivatives', Journal of Finance 52, 1323-1353.

Jensen, C. M. \& Meckling, H. W. (1976), 'Theory of the firm: Managerial behavior, agency costs and ownership structure', Journal of Financial Economics $3(4)$.

Jorion, P. (1990), 'The exchange rate exposure of u.s. multinationals', The Journal of Business 63(3), 331-345.

Mayers, D. \& Smith, W. C. (1982), 'On the corporate demand for insurance', Journal of Business 55, 281-296.

Mian, L. S. (1996), 'Evidence on corporate hedging policy', Journal of Financial and Quantitative Analysis 31, 419-439.

Myers, S. (1977), 'Determinants of corporate borrowing', Journal of Financial Economics 3, 305-360.

Newey, W. K. \& West, K. D. (1987), 'A simple, positive semi-definite, heteroskedasticity and autocorrelation consistent covariance matrix', Econometrica 55(3), 703-708. 
Novaes, W. \& Oliveira, F. N. (2007), The demand of foreign exchange derivatives in brazil. hedge or speculation?, Working Paper 152, Central Bank of Brazil. Mimeo.

Oliveira, F. N. (2004), 'The market of foreign exchange hedge in brazil: Reaction of financial institutions to interventions of the central bank'. Mimeo.

Smith, W. C. \& Stulz, M. R. (1985), 'The determinants of firms hedging policies', Journal of Financial and Quantitative Analysis 20, 391-405.

Stulz, M. R. (1984), 'Optimal hedging policies', Journal of Financial and Quantitative Analysis 19, 127-140.

\section{Appendix A}

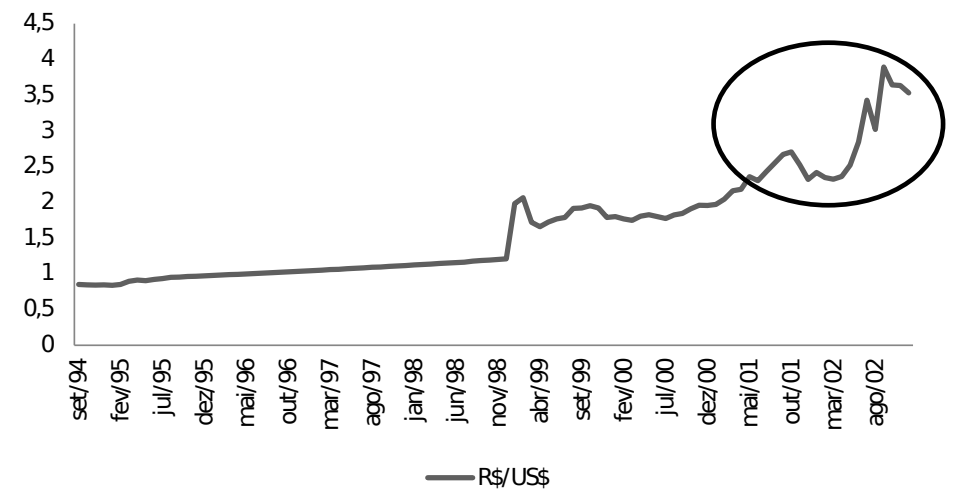

Figure A.1: Foreign Exchange rate in Brazil in our Sample Period

\section{Appendix B Financial Characteristics}

This table presents the financial and accounting characteristics of the firms that demanded currency swaps and of those that did not. The sample of the firms is formed by a group of 343 non-financial open capital corporations. They were not of the same economic group, divulged all of the necessary accounting information and have some form of exchange rate exposure. All of the information is from the end of the 2002 fiscal year, and relative to the financial statements that are available at CVM. The existence of external debt is equal to one when a firm possesses debt in dollars and zero otherwise; the participation of administrators in profit is equal to one when administrators participate in profit and zero otherwise; tax is equal to one when the firm pays tax and zero otherwise; institutional investors show the number of institutional investors of the firm; preferential shares are the book value of the firm's preferential shares. The number of observations of each characteristic is in the second column $(\mathrm{N})$. The $t$ statistics are presented for the average test between financial characteristics of the firms' diverse categories. P-values are in parentheses. 


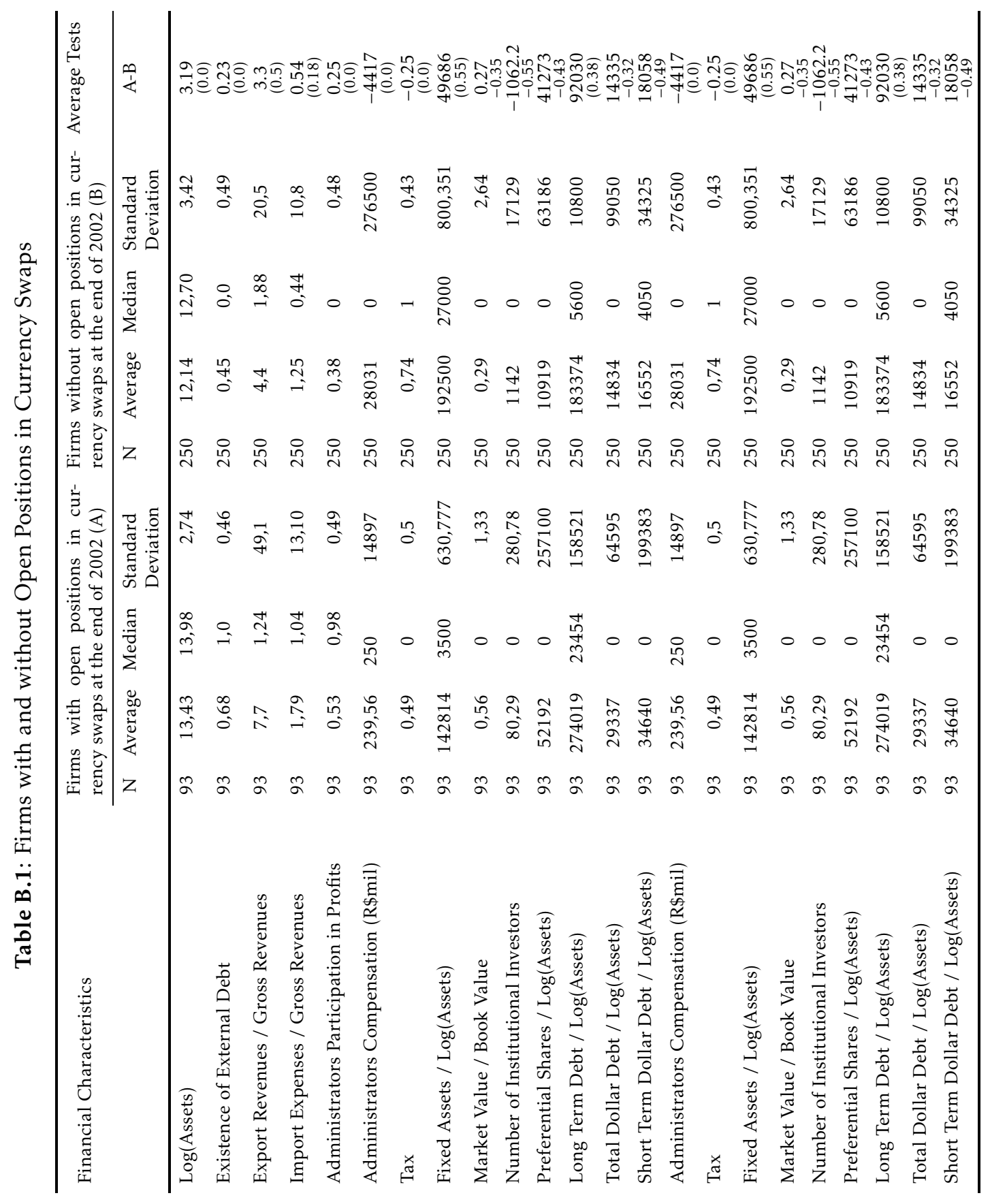




\section{Appendix C Hedge or Speculation}

Table C.1 presents the corporations with open contracts of currency swaps in 2002 by type of position: hedge, or speculation. Swaps/ NW is the average level in the industry of the ratio of net positions in currency swaps to net worth. Table C. 2 presents the firms that hedge and those that perform speculation classified by sectors; the form in which they do so and if they possess debt in dollars or not. Table C.3 presents the firms that hedge and those that perform speculation classified by sectors; the form in which they do so and if they have exports or imports in dollars. Table C. 4 shows the origin of the corporations that hedge, or that perform reverse or neutral speculation.

Table C.1: Types of Positions and Currency Exposures

\begin{tabular}{lcccccc}
\hline \multirow{2}{*}{ Industries } & \multicolumn{3}{c}{ Hedge } & \multicolumn{3}{c}{ Speculation } \\
\cline { 2 - 7 } & \multicolumn{3}{c}{ Net Position } & Swaps/NW & Net Position & Swaps/NW \\
\hline Chemical / Petroleum & 9 & 0 & 0.05 & 2 & 0 & 0.03 \\
Food and Beverages & 1 & 0 & 0.05 & 7 & 0 & 0.04 \\
Mining / Metallurgy & 2 & 0 & 0.01 & 0 & 0 & N.A. \\
Electro / Electronic & 6 & 0 & 0.08 & 5 & 0 & 0.026 \\
$\begin{array}{l}\text { Equipment } \\
\text { Transportation }\end{array}$ & 3 & 0 & 0.05 & 0 & 0 & N.A. \\
Utilities for Public Ser- & 19 & 0 & 0.06 & 0 & 0 & N.A. \\
vice & & & & & & \\
Textiles & 5 & 0 & 0.04 & 0 & 0 & N.A \\
Metallurgy & 6 & 0 & 0.07 & 2 & 0 & 0.03 \\
Other & 2 & 0 & 0.04 & 0 & 0 & N.A \\
\hline Total (long + short) & \multicolumn{5}{c}{53} & \multicolumn{5}{c}{16} & \\
\hline
\end{tabular}

Table C.2: Hedge and Reverse Speculation - With and Without Debt in Dollar

\begin{tabular}{|c|c|c|c|c|c|c|c|c|c|}
\hline \multirow{3}{*}{ Industries } & \multicolumn{4}{|c|}{ Hedge } & \multicolumn{4}{|c|}{ Speculation } & \multirow{3}{*}{ Total } \\
\hline & \multicolumn{2}{|c|}{ With Debt } & \multicolumn{2}{|c|}{ Without Debt } & \multicolumn{2}{|c|}{ With Debt } & \multicolumn{2}{|c|}{ Without Debt } & \\
\hline & Short & Long & Short & Long & Short & Long & Short & Long & \\
\hline $\begin{array}{l}\text { Chemical and } \\
\text { Petroleum }\end{array}$ & 9 & 0 & 0 & 0 & 1 & 0 & 1 & 0 & 11 \\
\hline Food and Beverages & 1 & 0 & 0 & 0 & 4 & 0 & 3 & 0 & 8 \\
\hline Mining and Metallurgy & 2 & 0 & 0 & 0 & 0 & 0 & 2 & 0 & 4 \\
\hline $\begin{array}{l}\text { Electro / Electronic } \\
\text { Equiptment }\end{array}$ & 6 & 0 & 0 & 0 & 3 & 0 & 2 & 0 & 11 \\
\hline Transportation & 3 & 0 & 0 & 0 & 0 & 0 & 0 & 0 & 3 \\
\hline $\begin{array}{l}\text { Utilities of Public Ser- } \\
\text { vice }\end{array}$ & 19 & 0 & 0 & 0 & 0 & 0 & 0 & 0 & 19 \\
\hline Textiles & 5 & 0 & 0 & 0 & 0 & 0 & 0 & 0 & 5 \\
\hline Metallurgy & 6 & 0 & 0 & 0 & 2 & 0 & 0 & 0 & 8 \\
\hline Other & 2 & 0 & 0 & 0 & 0 & 0 & 0 & 0 & 2 \\
\hline $\begin{array}{l}\text { Total (with debt }+ \text { with- } \\
\text { out debt) }\end{array}$ & 5 & & & 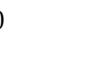 & 1 & 0 & & 0 & 63 \\
\hline
\end{tabular}


Table C.3: Hedge and Reverse Speculation — Exports and Imports

\begin{tabular}{|c|c|c|c|c|c|c|c|c|c|}
\hline \multirow{3}{*}{ Industries } & \multicolumn{4}{|c|}{ Hedge } & \multicolumn{4}{|c|}{ Speculation } & \multirow{3}{*}{ Total } \\
\hline & \multicolumn{2}{|c|}{ Exports } & \multicolumn{2}{|c|}{ Imports } & \multicolumn{2}{|c|}{ Exports } & \multicolumn{2}{|c|}{ Imports } & \\
\hline & Short & Long & Short & Long & Short & Long & Short & Long & \\
\hline $\begin{array}{l}\text { Chemical and } \\
\text { Petroleum }\end{array}$ & 4 & 0 & 3 & 0 & 1 & 0 & 0 & 0 & 8 \\
\hline Food and Beverages & 0 & 0 & 0 & 0 & 7 & 0 & 4 & 0 & 11 \\
\hline Mining and Metallurgy & 0 & 0 & 0 & 0 & 0 & 0 & 0 & 0 & 0 \\
\hline $\begin{array}{l}\text { Electro / Electronic } \\
\text { Equiptment }\end{array}$ & 3 & 0 & 3 & 0 & 5 & 0 & 2 & 0 & 13 \\
\hline Transportation & 1 & 0 & 0 & 0 & 0 & 0 & 0 & 0 & 1 \\
\hline $\begin{array}{l}\text { Utilities of Public Ser- } \\
\text { vice }\end{array}$ & 0 & 0 & 0 & 0 & 0 & 0 & 0 & 0 & 0 \\
\hline Textiles & 3 & 0 & 2 & 0 & 0 & 0 & 0 & 0 & 5 \\
\hline Metallurgy & 6 & 0 & 6 & 0 & 2 & 0 & 2 & 0 & 16 \\
\hline Other & 0 & 0 & 0 & 0 & 0 & 0 & 0 & 0 & 0 \\
\hline $\begin{array}{l}\text { Total (with debt + with- } \\
\text { out debt) }\end{array}$ & \multicolumn{2}{|c|}{17} & \multicolumn{2}{|c|}{14} & \multicolumn{2}{|c|}{15} & \multicolumn{2}{|c|}{8} & 54 \\
\hline
\end{tabular}

Table C.4: Hedge and Speculation — Origin of Capital

\begin{tabular}{lcc}
\hline Origin of Capital & Hedge & Speculation \\
\hline Domestic & 44 & 13 \\
State-owned & 5 & 1 \\
Multinational & 4 & 2 \\
\hline Total & 53 & 16 \\
\hline
\end{tabular}

\section{Appendix D Hedge and Speculation in Other Years}

Table D.1 presents the corporations with open contracts of currency swaps in 1999. by type of position: hedge, speculation. Table D.2 presents the corporations with open contracts in 2000 by type of position: hedge and speculation and Table D. 3 presents the corporations with open contracts in 2001 by type of position: hedge and speculation. The firm hedges when the product between its operational currency exposure, defined as the difference between export revenues and the sum of import expenses and debt in dollars, and its open positions in currency swaps is less than zero. The firm speculates when the product between its operational currency exposure, defined as the difference between export revenues and the sum of import expenses and debt in dollars, and its open positions in currency swaps is greater than zero. Swaps/ NW is the average level in the industry of the ratio of net positions in currency swaps to net worth. 
Table D.1: Hedge and Speculation 1999

\begin{tabular}{|c|c|c|c|c|c|c|}
\hline \multirow{3}{*}{ Industries } & \multicolumn{3}{|c|}{ Hedge } & \multicolumn{3}{|c|}{ Speculation } \\
\hline & \multicolumn{2}{|c|}{ Net Position } & \multirow{2}{*}{ Swaps/NW } & \multicolumn{2}{|c|}{ Net Position } & \multirow{2}{*}{ Swaps/NW } \\
\hline & Long & Short & & Long & Short & \\
\hline Chemical / Petroleum & 1 & 0 & 0.01 & 2 & 0 & 0.02 \\
\hline Food and Beverages & 1 & 0 & 0.06 & 2 & 0 & 0.07 \\
\hline Mining / Metallurgy & 0 & 0 & 0 & 0 & 0 & N.A. \\
\hline $\begin{array}{l}\text { Electro / Electronic } \\
\text { Equipment }\end{array}$ & 3 & 0 & 0.02 & 4 & 0 & 0.07 \\
\hline Transportation & 1 & 0 & 0.01 & 0 & 0 & N.A. \\
\hline $\begin{array}{l}\text { Utilities for Public Ser- } \\
\text { vice }\end{array}$ & 8 & 0 & 0.08 & 1 & 0 & 0.04 \\
\hline Textiles & 1 & 0 & 0.02 & 0 & 0 & N.A \\
\hline Metallurgy & 0 & 0 & 0.02 & 0 & 0 & 0.03 \\
\hline Other & 6 & 0 & 0.05 & 0 & 2 & 0.09 \\
\hline Total (long + short) & \multicolumn{2}{|c|}{21} & \multicolumn{4}{|c|}{9} \\
\hline
\end{tabular}

Table D.2: Hedge and Speculation 2000

\begin{tabular}{|c|c|c|c|c|c|c|}
\hline \multirow{3}{*}{ Industries } & \multicolumn{3}{|c|}{ Hedge } & \multicolumn{3}{|c|}{ Speculation } \\
\hline & \multicolumn{2}{|c|}{ Net Position } & \multirow{2}{*}{ Swaps/NW } & \multicolumn{2}{|c|}{ Net Position } & \multirow{2}{*}{ Swaps/NW } \\
\hline & Long & Short & & Long & Short & \\
\hline Chemical / Petroleum & 3 & 0 & 0.03 & 0 & 1 & 0.01 \\
\hline Food and Beverages & 2 & 0 & 0.04 & 1 & 0 & 0.01 \\
\hline Mining / Metallurgy & 0 & 0 & 0 & 0 & 0 & 0 \\
\hline $\begin{array}{l}\text { Electro / Electronic } \\
\text { Equipment }\end{array}$ & 4 & 0 & 0.06 & 0 & 0 & 0 \\
\hline Transportation & 2 & 0 & 0.02 & 0 & 1 & 0.03 \\
\hline $\begin{array}{l}\text { Utilities for Public Ser- } \\
\text { vice }\end{array}$ & 9 & 0 & 0.09 & 0 & 1 & 0.06 \\
\hline Textiles & 4 & 0 & 0.04 & 0 & 0 & 0 \\
\hline Metallurgy & 0 & 0 & 0.09 & 0 & 0 & 0 \\
\hline Other & 8 & 0 & 0.06 & 0 & 1 & 0.1 \\
\hline Total (long + short) & \multicolumn{2}{|c|}{32} & & \multicolumn{2}{|c|}{5} & \\
\hline
\end{tabular}

Table D.3: Hedge and Speculation 2001

\begin{tabular}{|c|c|c|c|c|c|c|}
\hline \multirow{3}{*}{ Industries } & \multicolumn{3}{|c|}{ Hedge } & \multicolumn{3}{|c|}{ Speculation } \\
\hline & \multicolumn{2}{|c|}{ Net Position } & \multirow{2}{*}{ Swaps/NW } & \multicolumn{2}{|c|}{ Net Position } & \multirow{2}{*}{ Swaps/NW } \\
\hline & Long & Short & & Long & Short & \\
\hline Chemical / Petroleum & 3 & 0 & 0.03 & 2 & 0 & 0.01 \\
\hline Food and Beverages & 2 & 0 & 0.04 & 4 & 0 & 0.01 \\
\hline Mining / Metallurgy & 0 & 0 & 0 & 0 & 0 & 0 \\
\hline $\begin{array}{l}\text { Electro / Electronic } \\
\text { Equipment }\end{array}$ & 4 & 0 & 0.06 & 5 & 0 & 0 \\
\hline Transportation & 2 & 0 & 0.02 & 0 & 0 & 0.03 \\
\hline $\begin{array}{l}\text { Utilities for Public Ser- } \\
\text { vice }\end{array}$ & 9 & 0 & 0.09 & 0 & 0 & 0.06 \\
\hline Textiles & 4 & 0 & 0.04 & 0 & 0 & 0 \\
\hline Metallurgy & 0 & 0 & 0.09 & 2 & 0 & 0 \\
\hline Other & 16 & 0 & 0.06 & 0 & 0 & 0.1 \\
\hline Total (long + short $)$ & \multicolumn{2}{|c|}{40} & \multicolumn{4}{|c|}{13} \\
\hline
\end{tabular}




\section{Appendix E Firms with More Liquids Stocks: Speculation and Hedge}

This table presents the financial and accounting characteristics of the firms that had more liquid stocks in Brazil with open positions in foreign exchange swaps at the end of 2002. We compare the financial characteristics of these firms with a group of 250 corporations that at the end of 2002 were not among the firms with more liquid shares and with our original group of 93 firms that had outstanding swap positions in foreign exchange rate. All of the information is from the end of the 2002 fiscal year, and relative to the financial statements that are available at CVM. The existence of external debt is equal to one when a firm possesses debt in dollars and zero otherwise; the participation of administrators in profit is equal to one when administrators participate in profit and zero otherwise; tax is equal to one when the firm pays tax and zero otherwise; institutional investors show the number of institutional investors of the firm; preferential shares are the book value of the firm's preferential shares. The number of observations of each characteristic is in the second column $(\mathrm{N})$. The $t$ statistics are presented for the average test between financial characteristics of the firms' diverse categories. The tests suppose equal variances unless the hypothesis is rejected at 5\%. P-values are in parentheses. 


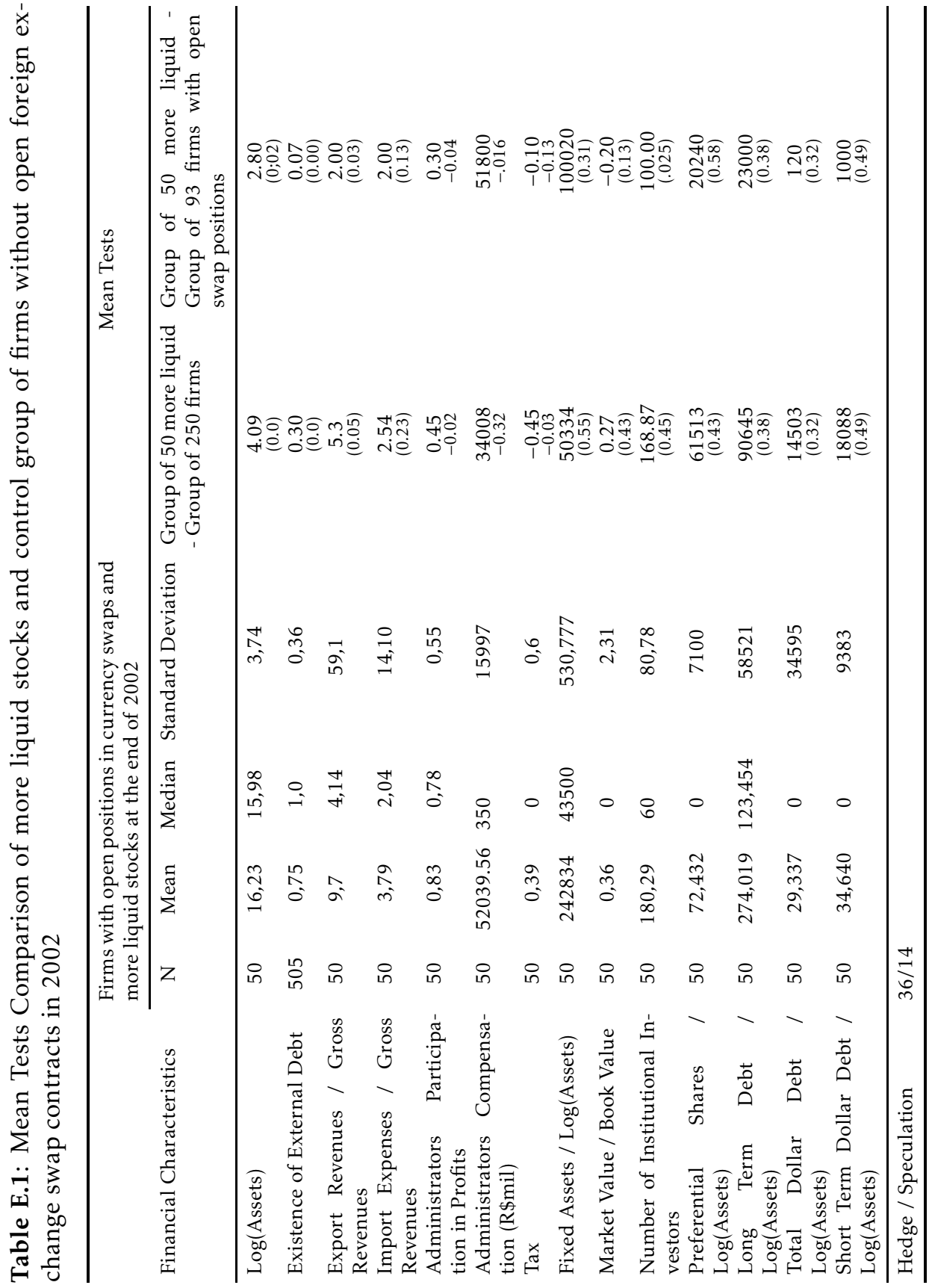




\section{Appendix F Foreign Exchange and Market Value: First Step Regressions}

In Table F.1 we estimate equation (1) in the text using OLS We estimate this regression for the years from 1999 to 2002 using OLS. We correct all regressions for heterocedasticity and autocorrelation when necessary with Newey \& West (1987). Below the estimated coefficients, in parentheses, are the p-values. In Table F. 2 we use weighted least squares to estimate a system of equations of the equation for all years using daily data.

Table F.1: Descriptive Statistics of Betas Univariate Estimation

\begin{tabular}{lrrrrr}
\hline & 1999 & 2000 & 2001 & 2002 & 1999 to 2002 \\
\hline Min & -0.46 & -0.65 & -0.61 & -0.68 & -0.41 \\
First Quartile & $(0.14)$ & $(0.10)$ & $(0.09)$ & $(0.08)$ & $(0.25)$ \\
Median & -0.24 & -0.36 & -0.42 & -0.48 & -0.39 \\
& $(0.15)$ & $(0.0)$ & $(0.21)$ & $(0.16)$ & $(0.04)$ \\
Third Quartile & 0.05 & 0.09 & 0.11 & 0.03 & 0.01 \\
Maximum & $(0.03)$ & $(0.04)$ & $(0.36)$ & $(0.23)$ & $(0.54)$ \\
Cross Sectional Mean & 0.31 & 0.50 & 0.48 & 0.53 & 0.37 \\
& $(0.14)$ & $(0.29)$ & $(0.31)$ & $(0.03)$ & $(0.0)$ \\
& 0.51 & 0.61 & 0.68 & 0.70 & 0.55 \\
Stability of firmsSame sign & $(0.0)$ & $(0.23)$ & $(0.02)$ & $(0.04)$ & $(0.0)$ \\
1999 and 2000 & -0.10 & -0.15 & 0.02 & 0.16 & -0.05 \\
2000 and 2001 & $34 \%$ & & & & $(0.35)$ \\
2001 and 2002 & $28 \%$ & & & & \\
2 subperiods & $84 \%$ & & & & \\
3 subperiods & $19 \%$ & & & & \\
\hline Number of Observations & 50 & 50 & 50 & 50 & \\
\hline
\end{tabular}

Table F.2: System Estimation with Weighted Least squares

\begin{tabular}{|c|c|c|c|c|c|c|c|c|}
\hline & \multicolumn{2}{|r|}{1999} & \multicolumn{2}{|r|}{2000} & \multicolumn{2}{|r|}{2001} & \multicolumn{2}{|r|}{2002} \\
\hline & $\begin{array}{l}\text { Avg } \\
\text { Expo- } \\
\text { sure }\end{array}$ & $\begin{array}{l}\text { Equal } \\
\text { foreign } \\
\text { exposure }\end{array}$ & $\begin{array}{l}\text { Avg } \\
\text { Expo- } \\
\text { sure }\end{array}$ & $\begin{array}{l}\text { Equal } \\
\text { foreign } \\
\text { exposure }\end{array}$ & $\begin{array}{l}\text { Avg } \\
\text { Expo- } \\
\text { sure }\end{array}$ & $\begin{array}{l}\text { Equal } \\
\text { foreign } \\
\text { exposure }\end{array}$ & $\begin{array}{l}\text { Avg } \\
\text { Expo- } \\
\text { sure }\end{array}$ & $\begin{array}{l}\text { Equal } \\
\text { foreign } \\
\text { exposure }\end{array}$ \\
\hline $\begin{array}{l}30 \text { firms } \\
\text { more } \\
\text { liquids }\end{array}$ & $\begin{array}{r}-0.36 \\
(0.45)\end{array}$ & $(0.22)$ & $\begin{array}{r}-0.65 \\
(0.10)\end{array}$ & $(0.02)$ & $\begin{array}{r}-0.85 \\
(0.15)\end{array}$ & $(0.12)$ & $\begin{array}{r}-0.68 \\
(0.08)\end{array}$ & $(0.0)$ \\
\hline $\begin{array}{l}50 \text { firms } \\
\text { more } \\
\text { liquids }\end{array}$ & $\begin{array}{r}-0.18 \\
(0.35)\end{array}$ & $(0.34)$ & $\begin{array}{r}-0.36 \\
(0.0)\end{array}$ & $(0.0)$ & $\begin{array}{r}-0.46 \\
(0.08)\end{array}$ & $(0.11)$ & $\begin{array}{c}-0.48 \\
0.16)\end{array}$ & $(0.03)$ \\
\hline $\begin{array}{l}\text { Firms that } \\
\text { speculated }\end{array}$ & $\begin{array}{l}(0.14 \\
(0.23)\end{array}$ & $(0.18)$ & $\begin{array}{l}(0.09 \\
(0.04)\end{array}$ & $(0.05)$ & $\begin{array}{l}(0.09 \\
(0.24)\end{array}$ & $(0.02)$ & $\begin{array}{l}(0.23 \\
(0.23)\end{array}$ & $(0.0)$ \\
\hline $\begin{array}{l}\text { Firms that } \\
\text { Hedged }\end{array}$ & $\begin{array}{c}-0.41 \\
(0.08)\end{array}$ & $(0.0)$ & $\begin{array}{c}-0.11 \\
(0.23)\end{array}$ & $(0.23)$ & $\begin{array}{c}-0.21 \\
(0.03)\end{array}$ & $(0.0)$ & $\begin{array}{c}-0.51 \\
(0.04)\end{array}$ & $(0.0)$ \\
\hline
\end{tabular}




\section{Appendix G Foreign Exchange and Market Value: Second Step Regressions 2002}

We estimate equation (2) in the text. We use OLS. The dependents variables are the exchange rate exposures. We regress them for every year against the following variables related to the theoretical reasons for firms to speculate and hedge with foreign exchange derivatives: ops is foreign operational exposure, defined as the difference between exports and the sum of imports and foreign exchange debt;spec is equal to 1 if the firms speculated, hedge is equal to 1 if the firm hedged; mult is equal to one if the firm is multinational; fixedassets is the total fixed assets of the firm divided by total assets; size is the the log of the total assets of the firms; mvbv is the quotient between the market value of firms and their book value; part is one if the executives have participation in the profits of the firms; II are the number of institutional investors of the firms. We correct for heterocedasticity when necessary with Newey \& West (1987). P-values are in parenthesis.

Table G.1: Foreign Exchange and Market Value: Second Step Regressions 2002

\begin{tabular}{|c|c|c|}
\hline & \multicolumn{2}{|c|}{ Exchange Rate Exposure } \\
\hline & (A) & (B) \\
\hline Constant & $\begin{array}{c}0.012 \\
(0.76)\end{array}$ & $\begin{array}{l}-0.053 \\
-0.03\end{array}$ \\
\hline Ops & $\begin{array}{l}0.24 \\
(0.06)\end{array}$ & $\begin{array}{l}0.27 \\
(0.05)\end{array}$ \\
\hline spec $^{*}$ ops & -0.0034 & $\begin{array}{c}-0.003 \\
(0.07)\end{array}$ \\
\hline Hedge ${ }^{*}$ ops & $\begin{array}{c}-0.48 \\
(0.06)\end{array}$ & $\begin{array}{c}-0.61 \\
(0.0)\end{array}$ \\
\hline Size & $\begin{array}{l}9.22 \\
(0.09)\end{array}$ & - \\
\hline mvbv & -0.00075 & - \\
\hline II & $\begin{array}{l}1.31 \\
(0.65)\end{array}$ & - \\
\hline fixedassets & $\begin{array}{l}0.92 \\
(0.09)\end{array}$ & - \\
\hline Part & $\begin{array}{l}-2.70 \\
(0.10)\end{array}$ & - \\
\hline Mult & $\begin{array}{c}-1.11 \\
(0.07)\end{array}$ & - \\
\hline Wald Test $\left(\right.$ ops $^{*}$ spec + ops $)=0$ & $\begin{array}{l}0.24 \\
(0.04)\end{array}$ & $\begin{array}{l}0.27 \\
(0.04)\end{array}$ \\
\hline Wald Test $\left(\right.$ ops $^{*}$ hedge + ops $)=0$ & $\begin{array}{l}-0.24 \\
(0.04)\end{array}$ & $\begin{array}{c}-0.34 \\
(0.0)\end{array}$ \\
\hline$R^{2}$ & 0.31 & 0.13 \\
\hline$R^{2} \operatorname{Adj}$ & 0.18 & 0.10 \\
\hline White Heterocedasticity & $(0.14)$ & $(0.04)$ \\
\hline F test & $(0.05)$ & $(0.02)$ \\
\hline Number of Observations & 50 & 50 \\
\hline
\end{tabular}




\section{Appendix H Foreign Exchange and Market Value: Second Step Regressions for 1999 to 2001}

We estimate equation (2) in the text. We use OLS. The dependent variables are the exchange rate exposures. We regress them for every year against the following variables related to the theoretical reasons for firms to speculate and hedge with foreign exchange derivatives: ops is foreign operational exposure, defined as the difference between exports and the sum of imports and foreign exchange debt; spec is equal to 1 if the firms speculated, hedge is equal to 1 if the firm hedged; mult is equal to one if the firm is multinational; fixedassets is the total fixed assets of the firm divided by total assets; size is the the log of the total assets of the firms; vmbv is the quotient between the market value of firms and their book value; part is one if the executives have participation in the profits of the firms; II are the number of institutional investors of the firms. We correct for heterocedasticity when necessary with Newey \& West (1987). P-values are in parenthesis.

Table H.1: Hedge and Speculation 2001

\begin{tabular}{|c|c|c|}
\hline & \multicolumn{2}{|c|}{ Exchange Rate Exposure } \\
\hline & (A) & (B) \\
\hline Constant & $\begin{array}{l}0.005 \\
(0.93)\end{array}$ & $\begin{array}{l}0.005 \\
(0.93)\end{array}$ \\
\hline Ops & $\begin{array}{l}0.21 \\
(0.19)\end{array}$ & $\begin{array}{l}0.21 \\
(0.19)\end{array}$ \\
\hline spec $^{*}$ ops & $-\frac{0.00086}{(0.06)}$ & $\begin{array}{r}-0.007 \\
(0.05)\end{array}$ \\
\hline Hedge $^{*}$ ops & $\begin{array}{r}-0.48 \\
(0.06)\end{array}$ & $\begin{array}{r}-0.61 \\
(0.0)\end{array}$ \\
\hline Size & $\begin{array}{c}2.3 \\
(0.05)\end{array}$ & - \\
\hline mvbv & $\begin{array}{r}-0.07 \\
(0.44)\end{array}$ & - \\
\hline II & $\begin{array}{r}-0.13 \\
(0.18)\end{array}$ & - \\
\hline fixedassets & $\begin{array}{l}0.17 \\
(0.37)\end{array}$ & - \\
\hline Part & $\begin{array}{c}0.13 \\
(0.30)\end{array}$ & - \\
\hline Mult & $\begin{array}{r}-0.39 \\
(0.02)\end{array}$ & - \\
\hline Wald Test $\left(\right.$ ops $^{*}$ spec + ops $)=0$ & $(0.01)$ & $(0.02)$ \\
\hline Wald Test $\left(\right.$ ops $^{*}$ hedge + ops $)=0$ & $(0.07)$ & $(0.01)$ \\
\hline$R^{2}$ & 0.24 & 0.24 \\
\hline$R^{2}$ Adj & 0.098 & 0.098 \\
\hline White Heterocedasticity & $(0.10)$ & $(0.01)$ \\
\hline F test & $(0.13)$ & $(0.23)$ \\
\hline Number of Observations & 50 & \\
\hline
\end{tabular}


Table H.2: Hedge and Speculation 2000

\begin{tabular}{lcc}
\hline & \multicolumn{2}{c}{ Exchange Rate Exposure } \\
\cline { 2 - 3 } & $(\mathrm{A})$ & $(\mathrm{B})$ \\
\hline Constant & 0.03 & -0.03 \\
Ops & $(0.43)$ & $(-0.08)$ \\
spec ${ }^{*}$ ops & 0.31 & 0.84 \\
Hedge*ops & $(0.09)$ & $(0.96)$ \\
Size & 0.076 & 1.8 \\
& $(0.36)$ & $(0.29)$ \\
mvbv & -0.35 & -0.02 \\
II & $(0.45)$ & $(0.45)$ \\
fixedassets & -0.09 & - \\
Part & $(0.24)$ & - \\
Mult & -0.23 & - \\
Wald Test (ops ${ }^{*}$ spec+ops) $=0$ & 0.47 & - \\
Wald Test (ops ${ }^{*}$ hedge+ops) $=0$ & $(0.17)$ & - \\
$R^{2}$ & 0.33 & \\
$R^{2}$ Adj & $(0.43)$ & - \\
White Heterocedasticity & -0.59 & - \\
F test & $(0.04)$ & $(0.015)$ \\
\hline Number of Observations & 0.44 & $(0.42)$ \\
\hline
\end{tabular}

Table H.3: Hedge and Speculation 1999

\begin{tabular}{|c|c|c|}
\hline & \multicolumn{2}{|c|}{ Exchange Rate Exposure } \\
\hline & (A) & (B) \\
\hline Constant & $\begin{array}{c}0.15 \\
(0.093)\end{array}$ & $\begin{array}{l}-0.28 \\
(-0.09)\end{array}$ \\
\hline Ops & $\begin{array}{c}0.31 \\
(0.29)\end{array}$ & $\begin{array}{c}0.89 \\
(0.06)\end{array}$ \\
\hline $\operatorname{spec}^{*}$ ops & $\begin{array}{l}0.76 \\
(0.16)\end{array}$ & $\begin{array}{l}1.34 \\
(0.21)\end{array}$ \\
\hline Hedge ${ }^{*}$ ops & $\begin{array}{r}-0.13 \\
(0.04)\end{array}$ & $\begin{array}{r}-0.01 \\
(0.87)\end{array}$ \\
\hline Size & $\begin{array}{c}0.08 \\
(0.04)\end{array}$ & - \\
\hline mvbv & $\begin{array}{r}-0.23 \\
(0.18)\end{array}$ & - \\
\hline II & $\begin{array}{l}0.27 \\
(0.17)\end{array}$ & - \\
\hline fixedassets & $\begin{array}{l}0.23 \\
(0.10)\end{array}$ & - \\
\hline Part & $\begin{array}{r}-0.56 \\
(0.04)\end{array}$ & - \\
\hline Mult & $\begin{array}{r}-0.67 \\
(0.34)\end{array}$ & - \\
\hline Wald Test $\left(\right.$ ops $^{*}$ spec + ops $)=0$ & $(0.18)$ & $(0.11)$ \\
\hline Wald Test $\left(\right.$ ops $^{\star}$ hedge + ops $)=0$ & $(0.67)^{*}$ & $\begin{array}{l}0.87 \\
(0.43)\end{array}$ \\
\hline$R^{2}$ & 0.19 & 0.11 \\
\hline$R^{2}$ Adj & $(0.09)$ & $(0.29)$ \\
\hline White Heterocedasticity & $(0.13)$ & $(0.86)$ \\
\hline F test & $(0.08)$ & $(0.25)$ \\
\hline Number of Observations & 50 & \\
\hline
\end{tabular}




\section{Appendix I Foreign Exchange and Market Value: Second Step Regressions Balanced Panel Analysis (Random Effects)}

We estimate equation (3) in the text. We use random effects. The dependent variables are the exchange rate exposures. We regress them for every year against the following variables related to the theoretical reasons for firms to speculate and hedge with foreign exchange derivatives: ops is foreign operational exposure, defined as the difference between exports and the sum of imports and foreign exchange debt; spec is equal to 1 if the firms speculated, hedge is equal to 1 if the firm hedged; mult is equal to one if the firm is multinational; fixedassets is the total fixed assets of the firm divided by total assets; size is the the log of the total assets of the firms; mvbv is the quotient between the market value of firms and their book value; part is one if the executives have participation in the profits of the firms; ii are the number of institutional investors of the firms. We correct for heterocedasticity when necessary with Newey \& West (1987). P-values are in parenthesis.

Table I.1: Foreign Exchange and Market Value: Second Step Regressions Balanced Panel Analysis (Random Effects)

\begin{tabular}{|c|c|c|}
\hline & \multicolumn{2}{|c|}{ Exchange Rate Exposure } \\
\hline & (A) & (B) \\
\hline Constant & $\begin{array}{r}-0.54 \\
(0.03)\end{array}$ & $\begin{array}{l}-0.015 \\
(0.0765)\end{array}$ \\
\hline Ops & $\begin{array}{l}0.31 \\
(0.07)\end{array}$ & $\begin{array}{l}0.52 \\
(0.03)\end{array}$ \\
\hline spec $^{*}$ ops & & \\
\hline spec $^{\star}$ ops $^{\star}$ y 2002 & $\begin{array}{r}0.03 \\
(0.04)\end{array}$ & $\begin{array}{l}0.05 \\
(0.01)\end{array}$ \\
\hline Hedge ${ }^{*}$ ops & $\begin{array}{r}-0.42 \\
(0.03)\end{array}$ & \\
\hline Hedge $^{\star}$ ops $^{\star}$ y 2002 & $\begin{array}{r}-0,13 \\
(0.00)\end{array}$ & $\begin{array}{r}-0.07 \\
(0.02)\end{array}$ \\
\hline Size & $\begin{array}{r}-0.23 \\
(0.04)\end{array}$ & - \\
\hline mvbv & $\begin{array}{r}-0.73 \\
(0.34)\end{array}$ & - \\
\hline II & $\begin{array}{l}0.012 \\
(0.39)\end{array}$ & - \\
\hline fixedassets & $\begin{array}{l}0.17 \\
(0.19)\end{array}$ & - \\
\hline Part & $\begin{array}{l}0.34 \\
(0.51)\end{array}$ & - \\
\hline Mult²002 & $\begin{array}{l}0.18 \\
(0.08)\end{array}$ & - \\
\hline$R^{2}$ Adj & 0.34 & 0.21 \\
\hline White Heterocedasticity & $(0.34)$ & $(0.52)$ \\
\hline F test & $(0.00)$ & $(0.04)$ \\
\hline Number of Observations & 50 & \\
\hline
\end{tabular}




\section{Appendix J Foreign Exchange and Market Value: Changing the Definition of Foreign Operational Exposure}

We changed our definition of foreign operational exposure in two different ways. In the first place, we extended the definition taking in consideration the net financial positions of firms in foreign exchange. To get we this we calculated the net position as the sum of the long positions in foreign exchange swaps with long position in other foreign exchange assets, like bonds or participation in firms abroad. In the second place, we moved to a more simple operational definition considering only exports minus imports. Table J.1 presents the results for net financial positions. Table J.2 presents the results for the operational definition. We estimate equation (2) in the text with these two new definitions. We correct for heterocedasticity when necessary with Newey \& West (1987). P-values are in parenthesis.

Table J.1: Financial Positions Definition

\begin{tabular}{|c|c|c|}
\hline & \multicolumn{2}{|c|}{ Exchange Rate Exposure } \\
\hline & (A) & (B) \\
\hline Constant & $\begin{array}{l}0.03 \\
(0.43)\end{array}$ & $\begin{array}{l}0.03 \\
(0.43)\end{array}$ \\
\hline Ops & $\begin{array}{l}0.31 \\
(0.09)\end{array}$ & $\begin{array}{l}0.81 \\
(0.09)\end{array}$ \\
\hline spec $^{*}$ ops & $\begin{array}{c}0.0076 \\
(0.04)\end{array}$ & $\begin{array}{l}0.56 \\
(0.36)\end{array}$ \\
\hline Hedge ${ }^{\star}$ ops & $\begin{array}{r}-0.51 \\
(0.05)\end{array}$ & $\begin{array}{r}-1.25 \\
(0.01)\end{array}$ \\
\hline Size & $\begin{array}{r}-0.09 \\
(0.24)\end{array}$ & - \\
\hline mvbv & $\begin{array}{r}-0.23 \\
(0.09)\end{array}$ & - \\
\hline II & $\begin{array}{l}0.47 \\
(0.17)\end{array}$ & - \\
\hline fixedassets & $\begin{array}{l}0.33 \\
(0.43)\end{array}$ & - \\
\hline Part & $\begin{array}{r}-0.59 \\
(0.04)\end{array}$ & - \\
\hline Mult & $\begin{array}{r}-0.07 \\
(0.08)\end{array}$ & - \\
\hline Wald Test $\left(\right.$ ops $^{*}$ spec+ops $)=0$ & $\begin{array}{l}0.31 \\
(0.01)\end{array}$ & $\begin{array}{l}1.37 \\
(0.15)\end{array}$ \\
\hline Wald Test $\left(\right.$ ops $^{\star}$ hedge + ops $)=0$ & $\begin{array}{r}-0.20 \\
(0.02)\end{array}$ & $\begin{array}{r}-0.44 \\
(0.01)\end{array}$ \\
\hline$R^{2}$ & 0.34 & 0.34 \\
\hline$R^{2}$ Adj & 0.32 & 0.28 \\
\hline White Heterocedasticity & $(0.66)$ & $(0.76)$ \\
\hline F test & $(0.08)$ & $(0.03)$ \\
\hline Number of Observations & 50 & \\
\hline
\end{tabular}


Table J.2: Operational Definition

\begin{tabular}{lcc}
\hline & \multicolumn{2}{c}{ Exchange Rate Exposure } \\
\cline { 2 - 3 } & $(\mathrm{A})$ & $(\mathrm{B})$ \\
\hline Constant & 0.009 & -0.04 \\
Ops & $(0.82)$ & $(0.04)$ \\
& 0.43 & 0.50 \\
spec ${ }^{*}$ ops & $(0.0)$ & $(0.0)$ \\
Hedge ops & 0.0 & -0.0006 \\
Size & $(0.06)$ & $(0.0)$ \\
& -1.87 & -1.50 \\
mvbv & $(0.14)$ & $(0.02)$ \\
II & -0.0006 & - \\
fixedassets & $(0.10)$ & \\
Part & 0.383 & - \\
Mult & $(0.10)$ & - \\
Wald Test (ops ${ }^{*}$ spec+ops) $=0$ & 0.78 & - \\
$R^{2}$ & $-0.52)$ & - \\
$R^{2}$ Adj & $(0.14)$ & - \\
White Heterocedasticity & 0.12 & - \\
F test & $(0.06)$ & - \\
\hline Number of Observations & $(0.83$ & 0.57 \\
\hline
\end{tabular}

